\title{
The Dynamics of Millennial Voters: How Political Marketing Affects Their Preference in 2019 Indonesian Presidential Election
}

\author{
Yuwanto \\ \{yuwantosaja@yahoo.com\} \\ Universitas Diponegoro, Indonesia
}

\begin{abstract}
Main objective of the research is describing how political marketing affects millennial voters' preference in 2019 Indonesian presidential election. General elections, including the presidential one, were held in Indonesia on 17 April 2019. Of the total 187 million voters, some 70 million are millennials, who are known as Generation Y. Their ages are between 17-35 years old and they are first time voters. Therefore, the participation of millennials in elections is crucial for the promotion of democracy in the country, given their large number. In case of presidential election, winning the support of the millennial generation is decisively important. The research is conducted in Semarang Municipal for 120 respondents taken with accidental sampling methods. By implementing the concept of political marketing, this study found that political marketing mix (product, price, place, promotion) affected millennials preference in the presidential election in various degree of significance. It showed that variables of place, price and product were positively and affected on their preference; while variable of promotion was affected but not significant.
\end{abstract}

Keywords: Election, Political Preference, Political Marketing, Millennial Voters.

\section{Introduction}

The phenomenon of political marketing in Indonesia is relatively new and its development experiences an extraordinary leap of progress. It can be seen from the 2014 presidential election won by Joko Widodo and Jusuf Kalla. Jokowi and his team had conducted a systematic strategy in preparing political issues, designing campaign themes, placing advertisements, hiring political consultants, and planning online and offline strategies for winning the campaign. Jokowi has succeeded in establishing positioning and personal branding as a symbol of democracy, his modesty through a humble attitude, friendly and sociable, makes him as a figure the people yearn for who has strong differentiation, compared to other candidates or other figures.

Wring in Firmanzah [1] stated that political marketing had actually conducted during the UK election in 1929. The conservative party was the first party to use a bureau agent (Holford-Bottomley Advertising Service) in designing and distributing posters and pamphlets. Rothschild in Firmanzah [1] states that advertisement plays an active role in the United States Presidential election since the era of President Abraham Lincoln in 1860.

There are many strategies in political marketing activities. In today globalization era, there are many media platforms used by the candidates to promote themselves. Sigmun 
Neumann in Budiardjo [2] defines a political party as an articulate organization consists of active political actors in community. These people are those who focus their attention on governmental power by gaining community support and competing with other groups with different perspectives. Millennials should also be considered for the success of 2019 general election. They are the generation with voters of age 17-35 years old. The percentage of millennials with right to vote is in the range of $30-45 \%$.

The year of 2019 is an important moment for Indonesian because this is the first time that Indonesia holds a simultaneous general election. It is called simultaneous because the people voted for President and Vice President, Members of House of Representatives (DPR RI), Regional Representative Council (DPD RI), Provincial and Regional House of Representatives (DPRD Provinsi/Kota/Kabupaten). Permanent Voters List (DPT) in 2019 based on General Election Commissioner (KPU) data is $192,828,520$ voters, with a total of $190,770,329$ people live in the country and 2,058,191 people abroad.

This is quite interesting to be studied deeper since Indonesian millennial voters are quite large in numbers. While the election, especially the presidential election (Pilpres) becomes the spearhead reflecting the Indonesia leadership. Various strategies performed by the candidates to attract the millennial voters, both directly and indirectly through their campaign teams. The research question is how is the effect of political marketing on millennials' decision in Semarang Municipal? The political marketing is important for both candidates to promote their vision, missions, and programs; and millennial voters who are interested to vote their desired candidates.

The Laswell Model [3] defines that political communication is associated with political marketing. Political marketing is the part of political communication. Political marketing is used in a narrower context and purpose. So, it can be stated that all political marketing activities are the parts of political communication, while, there are other parts of political communication that is excluded from political marketing. Political marketing is a process that begins with a series of information gathering, mapping, and analysis of all the problems, until then the formulation of the solution. In short, political marketing is the process by which political candidates promote themselves and their platforms to voters through masterly-crafted communications aimed at gaining public support.

According to Wring [4] the main product of a political party is a platform containing concept, identity, ideology and program. However, the platform cannot determine the selling price of political party. Wring [4] divides the principle of promotion through media into two parts that is paid and unpaid media. Niffenegger in Firmanzah [1] states that price in political marketing includes economical, psychological, and national image price. In general, Wring [4] states that place consists of local network, canvassing, and leader tour.

Firmanzah [1] states that as with any marketing applied to the business sector, political marketing consists of 4Ps, namely Product, Price, Promotion and Place. Product means the party, candidates and party ideas that will be presented by constituents. This product contains the concept, identity, and ideology that contribute to the formation of a political product. Promotion is the efforts of advertising, public relations and promotions for a party which are mixed in such a manner according to the needs of society. In this case the selection of media needs to be considered. Price includes economic, psychological, up to the national image. Economic price includes the cost of the party for the campaign. Psychological price refers to the price of psychological perception, for example, a sense of comfort with ethnic background, religion, education. National image price relates to whether voters feel the candidate can provide a positive image and became the pride of the State. Place is closely related to present or distribution means a party and his ability to communicate with voters. This means a party or 
candidate must be able to map the structure and characteristics of the people both geographic and demographic.

\section{Methodology}

This research used a descriptive quantitative method, namely explanatory. It was highlighting the effect between research variables and formulated testing hypotheses. Explanatory research according to Kerlinger [5] was testing the relationship among the hypothesized variables. The explanatory method was selected to explain the relationship among four political marketing variables on millennials voters' decision on 2019 presidential election. The population in this study was millennial voters in Semarang, taken randomly using accidental sampling technique or convenience sampling from first-time voters with certain characteristics; namely students of public high schools and private high schools (Islamic, Christian, Catholic schools). Ancok [6] states that the most widely used method to determine the instrument validity was to correlate the score obtained by each item with the total score. In this research the correlation coefficient between the score of items and total score was obtained through Pearson's Product Moment Correlation technique. The reliability of items was tested using Alpha-Cronbach variance analysis. The data processing was conducted using Statistical Packages for Social Sciences (SPSS) program for Windows Release 23. To test the major hypothesis, this research used regression analysis statistical technique.

\section{Discussion}

\subsection{Variable Analysis}

\subsubsection{Validity and Reliability Test}

Validity test measures the data validity obtained by the researcher through questionnaire as an instrument. The results and its correlation must be significant. The criteria to declare whether an item is valid or invalid is based on $r$ table, the minimum value of person correlation is 0.1779 because it uses 120 respondents $(\mathrm{N})$ with a limit of 0.05 . In addition, all person correlation values for each item is more than 0.1779 . This is marked with an * or ** in total column in output table, so 11 questionnaire items are valid (Table 1). The reliability test is conducted to determine whether the measuring instrument (questionnaire) indicates a consistency in measuring the same symptoms. A questionnaire is reliable if the answer to a statement is consistent and stable from time to time. The reliability test uses Cronbach Alpa, it usually uses a limit of $\geq 0.6$. The reliability test result for each variable is in the following data. Table 1 concludes that each variable has a Cronbach alpha of $\geq 0.60$ on 120 samples. Moreover, this result indicates that each indicator stated in the questionnaire is reliable.

Table 1. Validity and Reliability Test Result

\begin{tabular}{|c|c|c|c|c|}
\hline Variable & Indicator & Correlation Total Item & Description & Cronbach's Alpha \\
\hline $\begin{array}{c}\text { Political } \\
\text { Product }\end{array}$ & A1 & 0.472 & Valid & \multirow{2}{*}{0.617} \\
\cline { 2 - 4 } & A2 & 0.452 & Valid & \\
\hline
\end{tabular}




\begin{tabular}{|c|c|c|c|c|}
\hline \multirow{9}{*}{ (X1) } & A3 & 0.350 & Valid & \\
\hline & A4 & 0.312 & Valid & \\
\hline & A5 & 0.303 & Valid & \\
\hline & A6 & 0.356 & Valid & \\
\hline & A7 & 0.317 & Valid & \\
\hline & A8 & 0.363 & Valid & \\
\hline & A9 & 0.446 & Valid & \\
\hline & A10 & 0.466 & Valid & \\
\hline & A11 & 0.566 & Valid & \\
\hline \multirow{6}{*}{$\begin{array}{l}\text { Political Price } \\
\text { (X2) }\end{array}$} & B1 & 0.333 & Valid & \multirow{6}{*}{0.646} \\
\hline & B2 & 0.459 & Valid & \\
\hline & B3 & 0.531 & Valid & \\
\hline & B4 & 0.420 & Valid & \\
\hline & B5 & 0.322 & Valid & \\
\hline & B6 & 0.412 & Valid & \\
\hline \multirow{6}{*}{$\begin{array}{l}\text { Political } \\
\text { Promotion } \\
\text { (X3) }\end{array}$} & $\mathrm{C} 1$ & 0.401 & Valid & \multirow{6}{*}{0.633} \\
\hline & $\mathrm{C} 2$ & 0.333 & Valid & \\
\hline & C3 & 0.463 & Valid & \\
\hline & $\mathrm{C} 4$ & 0.496 & Valid & \\
\hline & $\mathrm{C} 5$ & 0.300 & Valid & \\
\hline & C6 & 0.480 & Valid & \\
\hline \multirow{6}{*}{$\begin{array}{l}\text { Political Place } \\
\text { (X4) }\end{array}$} & D1 & 0.502 & Valid & \multirow{6}{*}{0.641} \\
\hline & D2 & 0.535 & Valid & \\
\hline & D3 & 0.324 & Valid & \\
\hline & D4 & 0.470 & Valid & \\
\hline & D5 & 0.306 & Valid & \\
\hline & D6 & 0.402 & Valid & \\
\hline \multirow{5}{*}{$\begin{array}{l}\text { Voting Decision } \\
\text { (Y) }\end{array}$} & E1 & 0.484 & Valid & \multirow{5}{*}{0.649} \\
\hline & E2 & 0.566 & Valid & \\
\hline & E3 & 0.414 & Valid & \\
\hline & E4 & 0.416 & Valid & \\
\hline & E5 & 0.574 & Valid & \\
\hline
\end{tabular}

\subsubsection{Coefficient Determinant Analysis $\left(\mathbf{R}^{2}\right)$}

Based on Table 2, Adjusted R square is 0.532 or $(53.2 \%)$, this number indicates that about $53.2 \%$ of independent variables of political product, political price, political promotion, and political place affect the decision to vote. It means that the independent variables in the model are able to explain $53.2 \%$ of the dependent variable. While, the remaining $46.8 \%$ is affected by other variables excluded from this research.

Table 2. Determinant Coefficient Result

\begin{tabular}{|l|l|r|r|r|}
\hline \multicolumn{5}{|c|}{ Summary Model } \\
\hline Model & $\mathrm{R}$ & R Square & Adjusted R Square & Std. Error of the Estimate \\
\hline 1 & $.785^{\text {a }}$ & .613 & .532 & 1.932 \\
\hline a. Predictors: (Constant), Total X4, Total X2, Total X1, Total X3 \\
\hline
\end{tabular}




\subsubsection{F Test}

Based on Table 3, the calculated $F$ value is $46.276 \%$ with a significance level of 0.001 , meaning $<0.05$. So, it can be concluded that political marketing consists of political product, political price, political promotion, and political place can predict or explain their effects on millennial voters' decision in 2019 Presidential election.

Table 3. F Test Result

\begin{tabular}{|c|c|c|c|c|c|c|}
\hline \multicolumn{7}{|c|}{ ANOVA $^{b}$} \\
\hline Mode & & Sum of Squares & df & Mean Square & $\mathrm{F}$ & Sig. \\
\hline \multirow{3}{*}{1} & Regression & 402.299 & 4 & 100.575 & 46.276 & $.001^{\mathrm{a}}$ \\
\hline & Residual & 595,368 & 195 & 3.053 & & \\
\hline & Total & 875.962 & 199 & & & \\
\hline \multicolumn{7}{|c|}{ a. Dependent Variable: Total Y } \\
\hline \multicolumn{7}{|c|}{ b. Predictors: (Constant), Total X4, Total X2, Total X1, Total X3 } \\
\hline
\end{tabular}

\subsubsection{T test (Partial Regression Coefficient Test)} data is:

Based on Table 4, it can be stated that multiple linear regression result from the research

$$
Y: 0.583 X 1+0.526 X 2+0.221 X 3+0.475 X 4
$$

Based on the multiple linear regression analysis, here are the following conclusions:

a) X1 Regression coefficient of 0.583 regression coefficient is positive, meaning there is a positive effect of product on the voting decision. It indicates that the higher the political product received by respondents, the higher the millennial voters' decision in 2019 Presidential election. This is indicated by the significance value variable of 0.000 which is smaller than 0.05 .

b) $\mathrm{X} 2$ regression coefficient of 0.526 regression coefficient is positive. It means there is a positive effect of price on the voting decision. This number indicates that the higher the political price received by respondents, the higher the millennial voters' decisions in 2019 Presidential election, as indicated by a variable significance value of 0.000 which is smaller than 0.05 .

c) $\mathrm{X} 3$ regression coefficient of 0.221 regression coefficient is positive. It means there is a positive effect of promotion on the voting decision. Moreover, it indicates that political promotion gives an impact on the millennial voters' decision but not significant. This result is indicated by the variable significance value of 0.152 which is greater than 0.05 .

d) $\mathrm{X} 4$ regression coefficient of 0.475 regression coefficient is positive, meaning there is a positive effect of place on the voting decision. This number indicates that the higher political place, then the higher millennial voters' decision, indicated by the variable significance value of 0.001 which is smaller than 0.05 .

Table 4. T Test Result

\begin{tabular}{|c|c|r|r|c|c|r|}
\hline \multicolumn{2}{|c|}{ Coefficients $^{\mathrm{a}}$} \\
\hline \multirow{2}{*}{ Model } & \multicolumn{2}{|c|}{$\begin{array}{c}\text { Unstandardized } \\
\text { Coefficients }\end{array}$} & $\begin{array}{c}\text { Standardized } \\
\text { Coefficients }\end{array}$ & $\mathrm{t}$ & Sig. \\
\cline { 3 - 7 } & $\mathrm{B}$ & Std. Error & Beta & & \\
\hline 1 & (Constant) & 5.509 & 1.112 & & 4.272 & .000 \\
\hline
\end{tabular}




\begin{tabular}{|c|c|r|r|r|r|r|}
\hline & Total X1 & .126 & .034 & .583 & 3.905 & .000 \\
\hline Total X2 & .203 & .044 & .526 & 3.322 & .001 \\
\cline { 2 - 7 } & Total X3 & .083 & .033 & .221 & 1.213 & .152 \\
\cline { 2 - 7 } & Total X4 & .155 & .057 & .475 & 2.517 & .001 \\
\hline
\end{tabular}

\subsection{Analysis}

\subsubsection{Effect of Product (X1) on Millennial Voters' Decisions in the 2019 Presidential Election (Y)}

The result of partial test between product variable and millennial voters' decision in 2019 Presidential election is indicated by a significant value of $t 0.000$, meaning less than 0.05 . The respondents' responses to the delivered product indicates an average value of 3.81 and categorized as high. It means that political product offered to the public, mainly to the millennial voters affects their voting decision in 2019 presidential election. The point that a candidate must be intelligent is important, in addition to the issues during the campaign such as corruption, economic growth, ideology and law; all of them are essential for millennial voters. Each candidate promotes their campaign material as a form of political product or political promise to the public.

\subsubsection{Effect of Price (X2) on Millennial Voters' Decision in the 2019 Presidential Election} (Y)

Partial test between price variable on millennial voters' decision in the 2019 presidential election indicates that political price has a significant effect on millennial voters' decision partially as indicated by a significant $t$ value of 0.001 which is less than 0.05 . Millennial voters in Semarang give opinion that price (political price/cost) indicates the average value of responses by 3.08, and it is categorized as quite high. Political price, according to a research conducted through survey in Semarang, is quite influential in voting decision. However, this assumption is not a major factor in encouraging millennial voters to vote. Millennial voters think that the political price of a democratic party is important but it is not the main issue. They put more emphasis on the quality of the running candidates. Further, the important political price in a democratic party is incurred for advertising costs both through printed and electronic media such as television and the internet.

\subsubsection{Effect of Promotion (X2) on Millennial Voters' Decisions in the 2019 Presidential Election (Y)}

The result of partial promotion variable test on millennial voters' decision to vote in the 2019 Presidential election indicates no significant effect. This result is indicated by the significant value of $t, 0.152$, which is greater than 0.05 . Millennial voters assume that the political promotion by each candidate through media does not provide a great influent and impact on voting decision. This research also supports Firmanzah [1] stating that although the selection of promotional media needs to be considered, it does not mean that all media are appropriate as a venue for promotion. The responses of the respondent on political promotion indicate an average value of 3.26 which is categorized as high. The respondents state that advertisement on electronic and printed media (banners), and their social activities are only a 
medium to get some information about the potential partners but it does not give an impact on their decision in the 2019 Presidential election.

\subsubsection{Effect of Place (X4) on Millennial Voters' Decisions in the 2019 Presidential Election (Y)}

The partial test of place variable on millennial voters' decision in 2019 presidential election indicates a significant effect with t value of 0.001 . This number is less than 0.05 . In addition, the place variable indicates the highest average value among other variables, which is 4.14 and categorized as very high. It means that most respondent consist of millennial voters in Semarang agree on place indicator. The candidates visit to various regions is a must to attract community's interest in voting them. In addition, respondents agree to consider it as a contribution to nation. Further, millennial voters as the smart voters and have broad access to information and technology, prefer to keep their vote in the 2019 election as secret. Therefore, it is important for the candidates to promote their political promises to the public, and specifically to the millennial voters.

The result of $\mathrm{F}$ test between product, price, promotion and place on the voting decision can predict or explain the effects on millennial voters' decision in the 2019 election. Overall, the effect is significant because the significant $t$ value is 0.001 which is less than 0.005 . The distribution of respondents in this research consists of 16 sub-districts in Semarang.

\section{Conclusion}

Based on the analysis result, political marketing of product, promotion, price, and place, partly and jointly affect the millennial voters' decision in the 2019 presidential election in Semarang. The result of multiple linear regression proves that place is the dominant variable for millennial voters in the 2019 presidential election.

\section{References}

[1] Firmanzah, Marketing Politik: Antara Pemahaman dan Realitas. Jakarta: Yayasan Pustaka Obor Indonesia, 2008.

[2] M. Budiarjo, Demokrasi di Indonesia: Demokrasi Parlementer dan Demokrasi Pancasila. Jakarta: Gramedia, 1994.

[3] H. D. Lasswell, Structure a Function of Communication in Society. New York: Harper \& Bros, 2009.

[4] D. Wring, "Political marketing and party development in Britain: A 'secret' history.," Eur. J. Mark., vol. 30, no. 10, pp. 92-103, 1996.

[5] Kerlinger, Asas-Asas Penelitian Behavioral. Yogyakarta: Gajah Mada Press, 2000.

[6] D. Ancok, Teknik Penyusunan Skala Pengukur. Yogyakarta: Pusat Studi Kependudukan dan Kebijakan UGM, 2002. 